P-ISSN $2580-7781$

E-ISSN 2615 - 3238

\title{
UPAYA MENINGKATKAN SOLIDARITAS DAN POLA HIDUP SEHAT PADA MASA PANDEMI COVID-19 DI DESA PASIR PINANG KECAMATAN PORTIBI
}

\author{
EFFORTS TO IMPROVE SOLIDARITY AND HEALTHY LIVING \\ PATTERNS DURING THE COVID-19 PANDEMIC IN PASIR PINANG \\ VILLAGE, PORTIBI DISTRICT
}

\author{
Farida Jaya $^{\text {(), Fera Siska Nasution }{ }^{2)} \text {, Kiki Rimayanti Hasibuan }}{ }^{\text {() }}$, Lanina Siregar ${ }^{4)}$, \\ Rismawati Siregar $^{5)}$, Trinaningsih Rambe ${ }^{6}$ \\ 1,2,3,4,5,6 Universitas Islam Negeri Sumatera Utara Medan \\ ${ }^{1}$ Email: faridajaya@uinsu.ac.id
}

\begin{abstract}
ABSTRAK
Perbedaan silih pendapat sering terjadi di masyarakat, termasuk masyarakat Desa Pasir Pinang. Atas dasar ini, mahasiswa KKN DR 62 UIN SU Medan memandang penting mengupayakan peningkatan solidaritas dan juga pola hidup bersih di era pandemi Covid19. Penelitian ini bertujuan untuk menganalisa upaya meningkatkan solidaritas dan pola hidup masyarakat pada masa pandemi Covid-19 di Desa Pasir Pinang. Penelitian ini menggunakan pendekatan kualitatif dengan metode deskriptif. Proses pengumpulan data dilakukan dengan menggunakan teknik sosialisasi, wawancara, observasi serta dokumentasi. Selanjutnya, data dianalisa dengan teknik reduksi data, penyajian data dan verifikasi. Hasil dari kegiatan atau program yang telah dilaksanakan oleh mahasiswa dapat meningkatkan solidaritas antarmasyarakat di Desa Pasir Pinang, meliputi kegiatan gotong royong, membantu bidan desa dalam pelaksanaan imunisasi bayi, membantu anak SD dan PIAUD untuk belajar bersama, dan kegiatan wirid yasin tiap minggunya. Selain itu, kegiatan yang diprogramkan juga membantu sosialisasi pola hidup sehat pada masyarakat, seperti lari pagi, membagikan masker, melakukan penghijauan taman, dan membersihkan balai desa. Dengan demikian, diharapkan masyarakat menyadari pentingnya solidaritas antar sesama dan menjaga kesehatan mental dan fisik dengan menerapkan pola hidup sehat selama masa pandemi Covid-19.
\end{abstract}

Kata kunci: Covid-19, Kuliah kerja nyata, Perilaku hidup sehat, Solidaritas

\begin{abstract}
Differences of opinion often occur in the community, including the people of Pasir Pinang Village. On this basis, KKN DR 62 UIN SU Medan students see the importance of seeking to increase solidarity and also a clean lifestyle in the era of the Covid-19 pandemic. This study aims to analyze efforts to increase solidarity and people's lifestyles during the Covid-19 pandemic in Pasir Pinang Village. This study uses a qualitative approach with a descriptive method. The process of data collection was carried out using socialization techniques, interviews, observations and documentation. Furthermore, the data were analyzed using data reduction, data presentation and verification techniques. The results of activities or programs that have been carried out by students can increase solidarity between communities in Pasir Pinang Village, including mutual cooperation activities, assisting village midwives in implementing infant immunization, helping elementary and PIAUD children to study together, and wirid yasin activities every week. In addition, the programmed activities also help socialize healthy lifestyles to the community, such as jogging, distributing masks, reforesting the park, and cleaning the
\end{abstract}


P-ISSN $2580-7781$

E-ISSN 2615 - 3238

village hall. Thus, it is hoped that the community will realize the importance of solidarity between others and maintain mental and physical health by implementing a healthy lifestyle during the Covid-19 pandemic.

Keywords: Covid-19, Student study service, Healthy lifestyle, Solidarity.

\section{PENDAHULUAN}

Covid-19 merupakan virus RNA strain tunggal positif yang menginfeksi saluran pernafasan. Kita bisa atasi penyebaran virus Covid-19 lebih cepat dengan aksi yang tepat. Semua orang harus mengetahui informasi yang benar dan jangan terperangkap dalam hoaks dan informasi yang menyesatkan. Sebaiknya, terapkan anjuran pemerintah untuk tetap dirumah, pahami cara mencegah Covid-19 dengan memakai masker dan tetap mematuhi protokol kesehatan.

Kuliah Kerja Nyata merupakan sebuah bentuk pengabdian kepada masyarakat yang dilakukan oleh mahasiswa secara interdisipliner, institutional, dan kemitraan sebagai salah satu wujud dari UINSU Perguruan Tinggi. Program Pengabdian kepada masyarakat dipandang oleh UINSU Medan sebagai program yang wajib dilaksanakan. Kegiatan KKN DR Kelompok 62 di Desa Pasir Pinang diharapkan dapat memberikan edukasi kepada masyarakat untuk tetap waspada dan menerapkan pola hidup sehat selama masa pandemi Covid-19. Serta meskipun dalam keadaan dunia yang kurang sehat masyarakat juga diharapkan tetap menjaga solidaritas antar sesama.

Tujuan kegiatan KKN DR Kelompok 62 di Desa Pasir Pinang, Kec. Portibi, Kab. Padang Lawas Utara adalah mengedukasi masyarakat tentang pentingnya menjaga kesehatan mental dan fisik selama masa pandemi Covid-19, memberikan edukasi tentang solidaritas (kepedulian) antar sesama di masa pandemi.

\section{METODE PENELITIAN}

Penelitian ini menggunakan metode sosialisasi, wawancara, observasi, dokumentasi dan melakukan kunjungan secara langsung pada lokasi yang menjadi tempat atau objek KKN. KKN dilaksanakan di Desa Pasir Pinang, Kec. Portibi, Kab. Padang Lawas Utara dimulai pada tanggal 10 Juli-10 Agustus 2021. Field research atau penelitian lapangan merupakan jenis dari peneltian ini. Penelitian ini adalah penelitian deskriptif kualitatif (Moleong, 2014). Data dalam penelitian ini bersumber dari data primer dan sekunder. Data primer yaitu mahasiswa peserta 
P-ISSN $2580-7781$

E-ISSN 2615 - 3238

KKN KELOMPOK 62 DR UINSU yakni Mahasiswa Kelompok 62 dan masyarakat di lokasi KKN. Sedangkan data sekunder berupa dokumentasi. Metode pengumpulan data menggunakan observasi, wawancara, serta dokumentasi. Wawancara yang dilakukan untuk penelitian ini memiliki tujuan untuk mendapat informasi dari masyarakat tentang kebermanfaatan kegiatan Kuliah Kerja Nyata di tengah pandemi Covid-19. Adapun wawancara dilakukan kepada Mahasiswa dan masyarakat di lokasi KKN Mahasiswa. Sedangkan observasi merupakan pengamatan berupa rangkaian aktivitas untuk memusatkan fokus mengenai sebuah objek dengan segenap alat indera. Metode dokumentasi digunakan pada Penelitian ini sebagai pendukung data seperti data peserta KKN, lokasi KKN, dan kegiatan KKN.

\section{HASIL PENELITIAN DAN PEMBAHASAN}

Berdasarkan informasi dari hasil wawancara dengan mahasiswa diperoleh hasil bahwa kegiatan KKN pada masa pandemi Covid-19 harus menyesuaikan dan kegiatannya sangatlah terbatas. Hal tersebut menjadikan sisi positif maupun negatif bagi para Mahasiswa. Para informan mulai mengkaji dalam proses komunikasi sosial kepada masyarakat. Berdasarkan informasi yang diperoleh dari informan (Mahasiswa), maka dapat dianalisa bahwasanya Kuliah Kerja Nyata (KKN) ditengah pandemi tetap harus dilaksanakan sebagai bentuk wujud pengaplikasian Kelompok KKN DR 62 UINSU yaitu pengabdian kepada masyarakat. Dalam pelaksanaannya, KKN di masa pandemi sangat terbatas dalam hal kegiatan. Oleh karena itu, kegiatan KKN pada masa pandemi ini menyesuaikan dengan memperhatikan manfaat kegiatan tersebut kepada masyarakat. Mahasiswa dituntut mengembangkan kreativitas serta inovasi kegiatan saat ini sangatlah berguna apalagi melalui online. Namun, terkadang harus tetap terjun sebagai wujud interaksi sosial antara mahsiswa dengan masyarakat.

Berdasarkan hasil dari informan (masyarakat) diperoleh kesimpulan wawancara, menurutnya Kuliah Kerja Nyata (KKN) di masa pandemi Covid-19 ini sangatlah berbeda dari KKN sebelumnya. Namun masyarakat masih dapat merasakan kemanfaatan baik di bidang sosial maupun agama serta mendapat 
P-ISSN 2580 - 7781

E-ISSN 2615 - 3238

informasi dari mahasiswa sehingga esensi dari pengabdian ke masyarakat sendiri masih ada. Mahasiswa peserta KKN sebenarnya juga dituntut untuk terjun untuk menganalisis permasalahan di masyarakat dan membuat solusinya. Seperti dinyatakan para informan (masyarakat) seperti: "Terkait dengan informasi dari peserta KKN, kami lihat ada informasi baru terutama cara mencegah virus Covid-19”.

Dari pelaksanaan oleh peserta KKN ini, jika ada kegiatan sosial misal kerja bakti dan kegiatan keagamaan selalu ikut seperti tahlil, mengaji selalu ikut "Hubungan peserta KKN dengan masyarakat sekitar sangatlah baik dan sudah mengenal akrab kepribadian peserta KKN". Berdasarkan informasi yang diperoleh dari informan (Mahasiswa) tersebut diatas, maka dapat dianalisa bahwasanya Kuliah Kerja Nyata (KKN) pada masa pandemi ini dapat dikatakan masih memiliki urgensi terhadap pengabdian kepada masyarakat. Hal tersebut juga dirasakan oleh masyarakat yang merasakan masih adanya manfaat serta informasi dari peserta KKN. Kemudian juga peserta KKN dapat mengembangkan kemampuan serta keilmuwan selama belajar di Perguruan Tinggi dan di implikasikan kepada masyarakat. Hal ini sejalan dengan pernyataan Syardiansyah yang menyatakan bahwa:

"KKN memiliki peran untuk mengembangkan kepribadian mahasiswa untuk membentuk kepribadian yang terarah dan baik ditengah masyarakat, sebagai pengaplikasian dari ilmu yang diperoleh selama masa perkuliahan."

Pada kegiatan kuliah kerja nyata $(\mathrm{KKN})$ pada kelompok ini mengambil beberapa peran mahasiswa dalam pengabdian masyarakat, antara lain adalah:

\section{Solidaritas}

Hamidah (2011) dalam hukum Romawi dikatakan bahwa solidaritas menunjuk pada idiom "semua untuk masing-masing dan masing untuk semua." Tidak jauh dari hukum Romawi, bangsa Perancis mengaplikasikan terminologi solidaritas pada keharmonisan sosial, persatuan nasional dan kelas dalam masyarakat (Kolip dan Setiadi, 2011). Solidaritas sosial menunjuk satu keadaan hubungan antara individu dengan kelompok yang ada pada suatu komunitas 
P-ISSN 2580 - 7781

E-ISSN 2615 - 3238

masyarakat yang didasari pada moral dan kepercayaan yang dianut bersama yang diperkuat oleh pengalaman bersama (Ismawati, 2012; Johnson, 1986).

Menurut Jones (2010), solidaritas adalah keadaan saling percaya antara para anggota dalam suatu kelompok atau komunitas. Kalau orang saling percaya mereka akan menjadi satu/menjadi persahabatan, menjadi saling hormat menghormati, menjadi terdorong untuk bertanggung jawab dan memperhatikan kepentingan bersama. Konsep solidaritas sosial merupakan konsep sentral Emile Durkheim (1858-1917) dalam mengembangkan teori Sosiologi. Durkheim dalam Paul (1986) menyatakan bahwa solidaritas sosial merupakan suatu keadaan hubungan antara individu dan atau kelompok yang didasarkan pada perasaan moral dan kepercayaan yang dianut bersama dan diperkuat oleh pengalaman emosional bersama.

\section{Peran Mahasiswa pada Kegiatan KKN DR 62 UINSU dalam Meningkatkan Solidaritas di Desa Pasir Pinang}

Pola pembentukan solidaritas sosial dalam kelompok sosial antara mahasiswa dengan masyarakat di Desa Pasir Pinang Kecamatan Portibi adalah suatu cara untuk membentuk karakter dan kerukunan antara mahasiswa dengan masyarakat Pasir Pinang sehingga keharmonisan dan kerja sama akan terjalin baik antar mahasiswa maupun antar masyarakat. Dan pada akhirnya akan melahirkan generasi-generasi yang berkarakter yang dapat membawa perubahan yang lebih baik untuk bangsa dan negara. Dampak pola pembentukan solidaritas sosial dalam kelompok sosial antara mahasiswa dan Masyarakat di Desa Pasir Pinang di Kecamatan Portibi adalah terjadinya hubungan kerja sama, terjadinya keharmonisan, terhindarnya dari berbagai jenis konflik terciptanya keamanan, ketentraman dan tentunya hal yang paling penting adalah terbentuknya karakter mahasiswa yang mencerminkan sosok mahasiswa yang akan menjadi generasi emas di masa yang akan datang. Solidaritas merupakan hal yang penting dalam sebuah kelompok lingkungan masyarakat. Kehidupan yang terjadi pada individu berlangsung pada lingkungan masyarakat yang terbentuk karena adanya rasa solidaritas di dalam setiap individu dalam kelompok atau masyarakat. Pentingnya solidaritas dalam kehidupan dalam perspektif sosiologi adalah untuk sebagai alat 
P-ISSN $2580-7781$

E-ISSN 2615 - 3238

mencapai suatu tujuan dan keakraban dalam hubungan sosial setiap individu (Maryati \& Sryawati, 2007; Narwoko \& Suyanto, 2011).

Kegiatan yang dilaksanakan oleh Mahasiswa KKN DR 62 UINSU dalam Upaya Meningkatkan Solidaritas di Desa Pasir Pinang

a. Pengenalan/Memperkenalkan diri atau kelompok KKN DR 62 UINSU dengan tujuan agar masyarakat Pasir Pinang mengetahui maksud dan tujuan dari KKN DR 62 yang dilaksanakan di desa tersebut, guna menjaga solidaritas antara mahasiswa dan masyarakat terlaksana dengan baik.

b. Mahasiswa Melakukan Gotong Royong di Masjid Pasir Pinang seperti mencabut rumput, membersihkan masjid, guna agar tempat ibadah tetap terjaga dan bersih, dan akan lebih nyaman ketika melaksanakan salat. Dengan adanya kegiatan tersebut tentu mahasiswa sudah menjalankan perannya dengan baik dan masyarakat pasti merasa senang dan terbantu dan kegiatan ini juga termasuk meningkatkan rasa solidaritas antara mahasiswa dengan masyarakat.

c. Membagikan masker untuk masyarakat Desa Pasir Pinang, dengan tujuan mematuhi peraturan protokol kesehatan di tengah wabah Covid-19. Tujuannya untuk menjaga dari penyebaran wabah Covid-19.

d. Membantu guru PIAUD dalam mengajari anak-anak usia dini dalam proses belajar mengajar, di situ kami sebagai mahasiswa berperan ikut membantu dalam mengajari anak-anak mulai dari mempraktekkan gerakan-gerakan senam agar anak-anak sehat fisiknya, dan belajar menghapal doa-doa pendek seperti doa ibu bapak, makan, saat hujan turun, naik kendaraan, sesudah makan, dan lain sebagainya. Mahasiswa juga berperan mengajari anak-anak bernyanyi, dan mahasiswa juga mengajari anak- anak menulis huruf abjad dan angka. Dengan hadirnya mahasiswa KKN DR 62 kakak guru PIAUD tersebut merasa terbantu dan memudahkan pekerjaannya dalam mengajari anak-anak, tentu ini sudah menjadi kewajiban bagi mahasiswa, dalam melaksanakan peran meningkatkan solidaritas bagi anak-anak dan masyarakat Desa Pasir Pinang, Kec. Portibi.

e. Membantu anak-anak SD dalam pengerjaan soal-soal yang dikerjakan di rumah masing-masing, mahasiswa mencoba membantu anak-anak mengerjakan PR yang diberikan guru kepada muridnya, dan ini akan membantu anak-anak 
P-ISSN $2580-7781$

E-ISSN 2615 - 3238

tersebut dalam pendidikan yang lebih baik. Dengan adanya kegiatan ini akan meningkatkan solidaritas antara mahasiswa dengan anak-anak tersebut terjaga dengan baik.

f. Melakukan penghijauan, mahasiswa bergotong royong dengan baik dalam hal penghijauan dengan menanam bunga-bunga agar halaman yang tidak indah di pandang menjadi lebih indah, dan melakukan bercocok tanam, seperti menanam kangkung, bayam, tentu dengan adanya kegiatan ini masyarakat akan merasakan manfaat, dan akan meningkatkan solidaritas bagi mahasiswa dan masyarakat.

g. Membersihkan balai desa, mahasiswa berperan dalam melakukan kebersihan, mahasiswa berbagi bagi tugas mulai dari menyapu, mengepel lantai, dan lainnya, dan kepala desa merasa senang dengan dilakukan kegiatan tersebut.

h. Membantu Bidan dalam melakukan imunisasi, mahasiswa ikut serta dalam membantu kegiatan posyandu yang di lakukan di balai desa, seperti menimbang berat badan anak-anak Desa Pasir Pinang Kec. Portibi. Kegiatan ini juga akan meningkatkan rasa solidaritas mahasiswa dengan masyarakat Desa Pasir Pinang.

i. Membersihkan Kuburan-kuburan di Desa Pasir Pinang, mahasiswa melakukan kebersihan kuburan di Desa Pasir Pinang dengan remaja- remaja Pasir Pinang. Tujuannya supaya lebih bersih dan ini juga akan menjadi teladan yang baik bagi masyarakat Desa Pasir Pinang.

j. Mengikuti pengajian akbar atau wirid setiap Kamis dan Jumat di Desa Pasir Pinang, tentu ini sangat baik guna meningkatkan solidaritas bagi mahasiswa dan masyarakat dan akan menjadi contoh yang baik bagi mahasiswa.

k. Mengajari anak-anak dalam membaca surah ayat-ayat Al-Quran, mahasiswa mengajari anak-anak Desa Pasir Pinang membaca iqro dan Al-Quran dengan baik dan benar di Mesjid Pasir Pinang kec. Portibi.

1. Mengajari murid-murid Tsanawiyah dan Aliyah di pondok pesantren Almukhtariyah Sungai Dua, mahasiswa ikut berperan dalam proses belajar mengajar murid-murid di pondok pesantren sungai dua seperti mengajari membaca Al-Quran, mengajari nahwu, shorof, ski dan mata pelajaran lainnya. 
P-ISSN $2580-7781$

E-ISSN 2615 - 3238

Tentu ini sangat baik bagi pendidikan bagi generasi muda mudi dan akan meningkatkan solidaritas bagi murid-murid, mahasiswa dan guru-guru yang ada di pondok pesantren Al-Mukhtariyah Sungai Dua.

m. Lari pagi bersama anak-anak Desa Pasir Pinang Kec. Portibi, kelompok KKN DR 62 UINSU mengajak anak-anak lari pagi pada hari minggu ke Candi Bahal guna agar fisik anak-anak dan mahasiswa lebih sehat dan bugar tentu ini akan menjadi motivasi bagi anak-anak agar terlihat sehat dan terhindar dari penyakit. Dan di sini kami mahasiswa berperan untuk meningkatkan solidaritas dengan anak-anak menjadi lebih dekat, akrab dan anak-anak lebih menyayangi mahasiswa seperti kakak mereka sendiri.

Oleh karena itu diperlukan peran mahasiswa dalam masyarakat, dengan mengubah mindset agar belajar di rumah menjadi sebuah pengalaman yang menyenangkan. Sebagai contoh sikap tanggung jawab mahasiswa terhadap lingkungan, dengan melaksanakan kegiatan belajar yang menyenangkan yaitu dengan mengajak/mempelopori pemuda atau remaja memulai membangun ekonomi.

Sebagai kaum intelektual dan anggota mayarakat yang punya nilai tambah, mahasiswa untuk mampu memperankan diri secara profesional dan proporsional di masyarakat ataupun di dunia pendidikan. Peran mahasiswa tidak sekedar kegiatan pembelajaran di bangku perkuliahan, di perpustakaan dan aksess internet yang ada hubungannya dengan disiplin ilmu yang sedang ia tempuh tapi lebih dari itu. Mahasiswa bukan lulusan SLTA yang tidak sengaja terdampar di kampus. Mahasiswa memiliki tempat tersendiri di lingkungan masyarakat, namun bukan berarti memisahkan diri dari masyarakat. Oleh karena itu perlu dirumuskan perihal peran, fungsi, dan posisi mahasiswa untuk menentukan arah perjuangan dan kontribusi mahasiswa tersebut. Peran penting mahasiswa yang merupakan harapan dari masyarakan yakni peran sebagai agent of change, social control, iron stock dan moral force. Peran tersebut tentu saja untuk tidak diartikan sebagai peran berat ataupun disalah artikan yang pada ujungnya masyarakan antipati dengan kegiatan yang diselenggrakan oleh mahasiswa. Ide dan pemikiran cerdas seorang mahasiswa mampu merubah paradigma yang berkembang dalam suatu 
P-ISSN $2580-7781$

E-ISSN 2615 - 3238

kelompok dan menjadikannya terarah sesuai kepentingan bersama. Sikap kritis mahasiswa sering membuat sebuah perubahan besar dan membuat para pemimpin yang tidak berkompeten menjadi gerah dan cemas. Dan satu hal yang menjadi kebanggaan mahasiswa mahasiswa adalah semangat membara untuk melakukan sebuah perubahan.

\section{Pola Hidup Sehat Berbasis Keislaman di Masa Pandemi Covid-19}

Di masa pandemi Covid-19 seperti saat ini, pemerintah menghimbau kita untuk mengurangi kegiatan-kegiatan yang berhubungan dengan di luar rumah, sebagai antisipasi penyebaran virus Corona serta mengurangi bertambah nya jumlah pasien mengingat kasus jumlah pasien sudah mencapai ratusan, ribuan, bahkan sampai jutaan korban yang terserang sampai meninggal. Sehingga kita mau tidak mau harus meninggalkan kebiasaan kegiatan kita di luar rumah, seperti bekerja, berbelanja, bersosialisasi, bersekolah, bahkan beribadah yang kita sebut isolasi diri di dalam rumah.

Sadar atau tidak bahwa anjuran untuk tetap menjalankan pola hidup sehat serta berdiam diri di rumah sudah diajarkan oleh Islam sejak lama. Tertera dalam hadis-hadis juga dalam ayat suci Al-Qur'an, bahkan wabah penyakit seperti saat ini juga sudah lama ada sejak tahun kenabian. Dalam suatu riwayat mengatakan “Jika suatu kota/negara terkena wabah, maka jika kamu di dalamnya menetaplah, jangan keluar dari negara tersebut. Dan jika kamu hendak mengunjunginya maka kembalilah, jangan masuk ke dalam kota/negara tersebut”, kurang lebih seperti itulah bunyi dari suatu riwayat. Dalam hal itu kita bisa memahami bahwa wabah penyakit itu sudah ada dari dahulu bahkan jauh disaat tahun kenabian. Dan sudah dianjurkan untuk lebih baik berdiam diri di rumah dan membatasi interaksi sosial pada saat wabah penyakit sedang merajalela. Selain hal tersebut, didalam Islam juga diperintahkan untuk menjaga kesehatan tubuh dengan cara pola hidup sehat. Salah satunya yaitu dalam hal mencuci tangan. Kita dianjurkan untuk selalu mencuci tangan sebagai awalan dan akhiran kita dalam mengerjakan sesuatu. Pola hidup sehat yang dilakukan di Desa Pasir Pinang yaitu menjaga pola makan, sholat, pola tidur, olahraga, kebersihan lingkungan sekitar agar tidak menimbulkan terjangkitnya penyakit. Pola makan misalnya, dengan menjaga 
P-ISSN 2580 - 7781

E-ISSN 2615 - 3238

keseimbangan tubuh dengan puasa yang secara medis memang mampu membersihkan tubuh dari racun-racun atau sampah metabolisme tubuh.

\section{KESIMPULAN}

Berdasarkan hasil penelitian dan pembahasan dalam penelitian ini, maka dapat ditarik kesimpulan bahwa penyebab terjadiya konflik di dalam masyarakat yaitu adanya perbedaan yang sering terjadi di masyarakat. Berdasarkan temuan peneliti diketahui bahwa KKN pada saat pandemi masih memiliki kebermanfaatan serta dapat mengambarkan wujud pengabdian kepada masyarakat. $\mathrm{KKN}$ di masa pandemi tetap harus dilakukan sebagai wujud pengabdian kepada masyarakat serta pengimplementasian ilmu dari mahasiswa yang diperoleh ketika di bangku perkuliahan. Kegiatan KKN juga tetap memerhatikan protokol kesehatan dengan cara membatasi kegiatan serta menaati anjuran pemerintah. Rekomendasi untuk peneliti selanjutnya yakni dengan menambah dari berbagai perspektif keilmuan atau dapat mencoba meneliti mengenai pengaruh dengan berbagai jenis penelitian. Meskipun demikian, solidaritas masih tetap terjaga di dalam masyarakat. Serta tetap menjaga pola hidup sehat meskipun dalam kondisi Covid-19 seperti yang sudah dianjurkan di dalam hadis nabi.

\section{DAFTAR PUSTAKA}

Ismawati, E. 2012. Ilmu Sosial Budaya Dasar. Yogyakarta: Penerbit Ombak.

Jones, P.I.P. 2010. Pengantar Teori-teori Sosial. Jakarta: Yayasan Pustaka Obor Indonesia.

Johnson, D.P. 1986. Teori Sosiologi Klasik dan Modern. Terj. Robert M. Z. Universitas of South Florida. Jakarta: Gramedia.

Kolip, U. \& Setiadi, E.M. 2011. Pengantar Sosiologi. Jakarta: Kencana.

Maryati, K. \& Sryawati, J. 2007. Sosiologi untuk SMA dan MA Kelas XI. Jakarta: Erlangga Media Group.

Moleong, L.J. 2014. Metodologi Penelitian Kualitatif. Bandung: Remaja Rodaskarya.

Narwoko, D. \& Suyanto, B. 2011. Sosiologi Teks Pengantar dan Terapan. Edisi Keempat. Jakarta: Prenada Media Group. 